\title{
TRANSPORT EMISSIONS AND ELECTRIC MOBILITY IN PRIVATE TRANSPORT IN THE REPUBLIC OF SLOVENIA
}

\author{
Simon MUHIČ, Ante ČIKIĆ, Jadran PIŠTAN, Marinko STOJKOV, Mladen BOŠNJAKOVIĆ
}

\begin{abstract}
Since the ratification of the Kyoto Protocol more and more emphasis is laid on reducing greenhouse gas emissions. The article analyses the feasibility of introducing electric vehicles into traffic rather than vehicles with internal combustion engines. From standpoint of emission sources use of electricity for transport is analysed with stress on private cars and typical emissions from power sector by energy conversion in Slovenia. Results of research shows that electric car has a little more than twice better efficiency of the primary energy use, taking into account only efficiency in the energy chain. Electric mobility brings a more efficient use of energy in road transport with demand to reduce emission at power generation. So presented number can vary greatly, depending on the electrical energy source. In the present research problems connected with immediate initiation of the electric cars are not analysed.
\end{abstract}

Keywords: electric mobility; electric vehicles; emissions; transport

\section{INTRODUCTION}

Energy use in the transport sector in Slovenia represents around $40 \%$ of total energy use. For this purpose, mainly imported petroleum products are used. Introduction of alternative fuels, emphasizing electric mobility, is a prioritized task in the field of transport, as well as in the current proposed orientations for preparing the new energy concept of the Republic of Slovenia.

In the last decade, transport took over the first place among the sectors regarding the energy use, namely in 2002, it represented $32 \%$ of end energy use in Slovenia. Today it has grown to just above $40 \%$. The end energy use in 2007 amounted to $4954 \mathrm{ktoe}$. In the period from 1992 to 2007 , it increased by $49 \%$; the majority of growth occurred in 1997 and it continues to rise. Transport energy use is almost exclusively (99 \%) based on fossil fuels, resulting in a constant increase of the greenhouse gas emissions [1].

Nowadays, electric drive cars are no longer rare, since all automotive concerns and a significant number of institutes engage in their development, but although a lot has been written and spoken about the electric cars, electric transport is still a distant vision, at least on Slovenian roads, as only a small number of electric representatives can be found [2].

In 2014, 153 electric vehicles (EV) were registered in Slovenia, i.e. only around $0,01 \%$ of all vehicles [2] of which 133 were private cars, however, at the end of 2015 , from 1437444 registered vehicles 599 were electric, which amounts to approximately $0,04 \%$ of all vehicles [3]. From the statistics it can be identified that electrically powered vehicles are on the rise, but according to the national energy programme, by 2020 the number of them should represent $2,7 \%$ of vehicle fleet. Introduction of alternative fuels, putting an emphasis on electric mobility, is a prioritized task in the field of transport, as well as in the current proposed orientations for preparing the new energy concept of the Republic of Slovenia [4].
Fig. 1 shows the shares in energy use by sectors in Slovenia since 1992 and how it has been increasing over the years until today. The increase can also be linked with the previously mentioned data on the increase in the number of registered vehicles. It is visible that the share of the end energy use in transport is $39,5 \%$ for the year 2014 [1].

It can be concluded that replacing the energy source for just over $40 \%$ of the end energy use represented by transport today would have a significant effect on emissions. As a result, we could expect lower emissions and less harmful impact on the natural and urban environment. Nevertheless, the change that would occur in this case must not to be overlooked. The primary energy from mainly imported fossil fuels of petroleum origin is replaced with electrical energy. At the same time, we face the problem of emissions in the conversion of fuels into electrical energy. The future society will have to be based on a high proportion of renewable energy sources (RES) for supplying energy. This is necessary to control climate change and to boost competitiveness and reliability of the energy supply [5]. The main problem is motor transport, where a positive trend of reducing emissions due to the advancement in vehicle fleet is seen, however, because of the increasing number of vehicles these effects are diminishing. Due to the increased number of motor vehicles and numerous migrations, the use of motor fuels has risen and consequently, the emissions have as well. It is assumed that the growing transport is a heavy burden for the environment; that it is in the interest of all to reduce the emissions from transport; that initiation of different technologies in transport is needed, and with the correct attitude, electric transport would mean larger energy independence and more stable economy [6]. The greenhouse gases from transport in Slovenia increased from 1986 to 2012 by $185 \%$; as well as elsewhere in Europe the greenhouse gas (GHG) emissions from transport are higher than the overall growth. In the area of the first EU member states, from 1990 to 2012, the GHG emissions increased by 
$9 \%$, moreover, in the whole current EU area by $14 \%$ (in Slovenia in the same period by $111 \%$ ). The most greenhouse gas emissions in transport are caused by road transport, which generates $99,2 \%$. A relatively high proportion of transport emissions in relation to total emissions (31\% in 2012) and not enough strict measures for their reduction complicate the commitment of Slovenia to achieve the Kyoto Protocol commitments [7]. Fig. 1 shows shares of sectors in the end energy use in period 1992 -2014 .

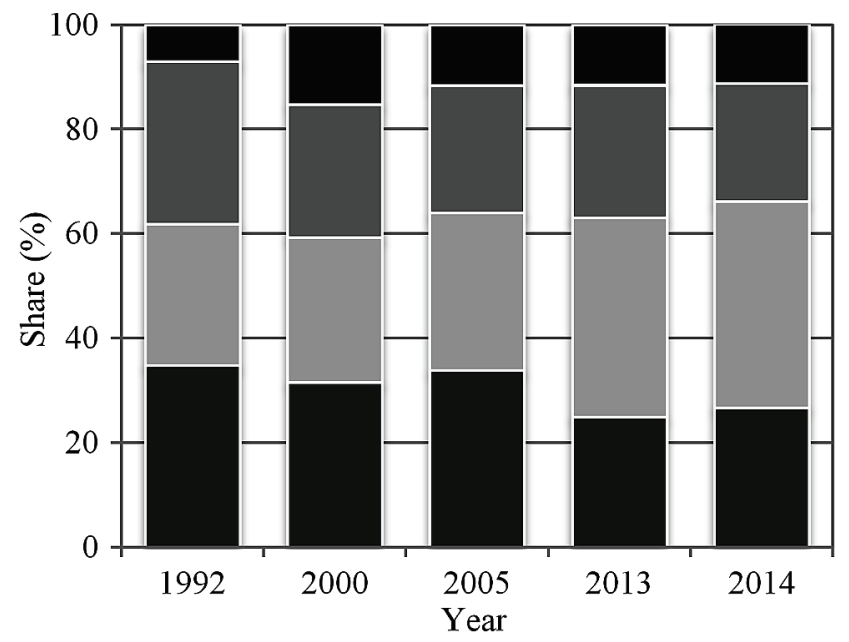

- Other $\square$ Households $\square$ Transport $\square$ Manufacturing and construction Figure 1 Shares of sectors in the end energy use [1]

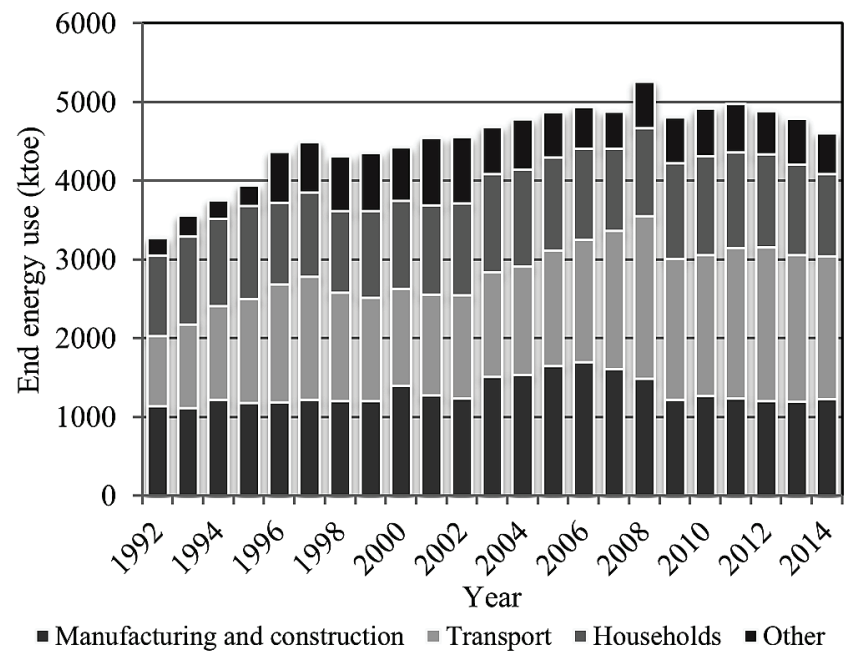

Figure 2 The end energy use across sectors [1]

Fig. 2 shows total end energy use in "ktoe" in Slovenia in the same period. With the National Energy Efficiency Action Plan 2014-2020 (AN URE 2020), according to the requirements of Energy Efficiency Directive 2012/27/EU, Slovenia has set an indicative target for improving energy efficiency by 2020 , concluding that primary energy use will not surpass 7125 million toe in 2020, meaning it may not exceed the 2012 data for more than $2 \%$, and sets the national target of improving energy efficiency by $20 \%$ until 2020 [8].

\section{ENERGY IN TRANSPORT}

Through membership in the European Union, Slovenia has committed itself to achieving of the target values for emissions of greenhouse gases defined in the Kyoto Protocol. Transport is the sector in which the most of fossil fuels is spent. In 2012, the energy use in transport amounted to $1953 \mathrm{ktoe}$. According to the previous year, it increased by almost $2 \%$, and by $59 \%$ in comparison to the year 2000; in comparison to the year 1992, it was higher by $120 \%$. In 2008, when the maximum in the observed period was reached, it decreased by $6 \%$. By far the most energy was used by road transport, which in 2012 represented more than $97 \%$ of the total use. The share of transport regarding the total end energy use in Slovenia, which in 1992 amounted to $24,4 \%$, in 2002 increased to $31,6 \%$. Energy use in transport is almost exclusively in $99 \%$ based on fossil fuels, among which in 2011 the diesel fuel strongly dominated with $65,0 \%$, followed by the petrol fuel with $30,8 \%$. Liquid fuels, the usage of which is still increasing in the transport sector, remain the most important energy source with $51 \%$ share. Unlike the transport, energy use in industry is decreasing.

In the current state of technology, motorcycles, private cars and small delivery vehicles are already suitable for transition to electric drive. In 2010 in Slovenia, these types of vehicles represented $85 \%$ of all motor vehicles in road transport, their fuel use amounted to $73,5 \%$ of total use in road transport, and the share of $\mathrm{CO}_{2}$ emissions was $73,9 \%$ [9]. The mentioned shares and numbers point out that, based on new technologies, e-mobility plays an important role in protecting the environment and ensuring the sustainable energy use.

Table 1 Structure of energy use in transport [10]

\begin{tabular}{|l|c|c|c|c|c|c|}
\hline & & 2000 & 2005 & 2010 & 2012 & 2013 \\
\hline Cars & $\%$ & 73,6 & 67,4 & 61,9 & 62,2 & 62,1 \\
\hline Freight vehicles & $\%$ & 19,5 & 26,4 & 32,9 & 33,6 & 33,6 \\
\hline Buses & $\%$ & 2,7 & 2,4 & 1,9 & 1,3 & 1,2 \\
\hline Motorcycles & $\%$ & 0,1 & 0,3 & 0,4 & 0,4 & 0,4 \\
\hline Railways & $\%$ & 1,9 & 1,9 & 1,3 & 1,2 & 1,2 \\
\hline Airplanes & $\%$ & 2,1 & 1,6 & 1,6 & 1,3 & 1,5 \\
\hline
\end{tabular}

Tab. 1 shows the structure of energy use in transport in Slovenia in period $2000-2013$. For example during 2013 private vehicles represent $62,1 \%$ of energy use in transport, which is $33 \%$ of the end energy use. Tab. 2 shows the sources of distributed electrical energy in 2014 and information on emissions, as well as the radioactive waste per $\mathrm{kW} \cdot \mathrm{h}$ produced in Slovenia. The majority of electrical energy is from fossil fuels $(47,86 \%)$ and of nuclear origin $(38,76 \%)$ [11] and only $13,37 \%$ of electrical energy comes from renewable energy sources.

Tab. 3 shows the quantities of electrical energy on the power plants threshold in Slovenia in period 2012 - 2014. The last column shows the part produced for Croatia. The total production in Slovenia is thus the sum of production in the first column and the last column. 


Table 2 The share of electrical energy sources [11]
\begin{tabular}{|l|c|}
\hline Fossil fuels & $47,86 \%$ \\
\hline Coal and lignite & $40,17 \%$ \\
\hline Natural gas & $4,71 \%$ \\
\hline Petroleum products & $0,17 \%$ \\
\hline Unidentifiable & $2,81 \%$ \\
\hline Nuclear fuel & $38,76 \%$ \\
\hline Renewable energy sources & $13,37 \%$ \\
\hline Hydropower & $11,58 \%$ \\
\hline Wind & $0,05 \%$ \\
\hline Solar energy & $0,89 \%$ \\
\hline Wood biomass & $0,00 \%$ \\
\hline Geothermal energy & $0,32 \%$ \\
\hline Landfill gas & $0,13 \%$ \\
\hline Sewage treatment plant gas & $0,00 \%$ \\
\hline Biogas & $0,38 \%$ \\
\hline Biodiesel & $0,01 \%$ \\
\hline Unidentifiable & $0,01 \%$ \\
\hline Total & $100,00 \%$ \\
\hline
\end{tabular}

(construction and processing), transport, households and by other users (services and other use), and does not include the conversion and transmission losses, the energy sector's own use and non-energy related use. Also, capacity of power plants in Slovenia is in slightly increase during observed period, from $3351 \mathrm{MW}$ in 2012 till $3453 \mathrm{MW}$ in 2014.

Table 3 Quantities of electrical energy (EE) and installed capacity of power plants in Slovenia [12]

\begin{tabular}{|c|c|c|c|c|}
\hline Year & $\begin{array}{c}\text { Production } \\
(\mathrm{GW} \cdot \mathrm{h})\end{array}$ & $\begin{array}{c}\text { End use } \\
(\mathrm{GW} \cdot \mathrm{h})\end{array}$ & $\begin{array}{c}\text { Capacity } \\
(\mathrm{MW})\end{array}$ & $\begin{array}{c}\text { Croatia } \\
1 / 2 \text { EE from } \\
\text { NPP Krško } \\
(\mathrm{GW} \cdot \mathrm{h})\end{array}$ \\
\hline 2014 & 13456 & 12560 & 3453 & 3030 \\
\hline 2013 & 12599 & 12587 & 3434 & 2518 \\
\hline 2012 & 12083 & 12540 & 3351 & 2622 \\
\hline
\end{tabular}

The end use of energy, i.e. the end energy use or the energetic end use is the energy, used in industry sectors

Table 4 Emissions from electrical energy conversion [14]

\begin{tabular}{|c|c|c|c|c|c|c|c|}
\hline $\mathrm{Gas}$ & Unit of measurement & 2009 & 2010 & 2011 & 2012 & 2013 & 2014 \\
\hline $\mathrm{CO}_{2}$ & $\mathrm{~kg} \mathrm{CO} / \mathrm{kW} \cdot \mathrm{h}$ & 0,480 & 0,491 & 0,516 & 0,497 & 0,450 & 0,316 \\
\hline $\mathrm{CH}_{4}$ & $\mathrm{~kg} \mathrm{CH} / \mathrm{kW} \cdot \mathrm{h}$ & 0,00016 & 0,00015 & 0,00016 & 0,00016 & 0,00013 & 0,00011 \\
\hline $\mathrm{N}_{2} \mathrm{O}$ & $\mathrm{kg} \mathrm{N} / \mathrm{O} / \mathrm{kW} \cdot \mathrm{h}$ & 0,00188 & 0,00190 & 0,00204 & 0,00197 & 0,00178 & 0,00137 \\
\hline Total GHG & $\mathrm{kg} \mathrm{CO}-\mathrm{eq} / \mathrm{kW} \cdot \mathrm{h}$ & 0,483 & 0,493 & 0,519 & 0,499 & 0,452 & 0,317 \\
\hline
\end{tabular}

Table 5 Emissions in 2013 in Slovenia from energy use across sectors [15]

\begin{tabular}{|c|c|c|c|c|c|c|}
\hline Unit & $\begin{array}{c}\text { Non-energy related } \\
\text { sources }\end{array}$ & $\begin{array}{c}\text { Electricity and heat production (incl. } \\
\text { fugitive emissions) }\end{array}$ & $\begin{array}{c}\text { Industry and construction } \\
\text { (energy use of fuels) }\end{array}$ & Transport & $\begin{array}{c}\text { Other } \\
\text { (wide use) }\end{array}$ & Total \\
\hline $\mathrm{kt} \mathrm{CO}_{2}$-eq & 3287,6 & 6230,9 & 1641,5 & 5459,1 & 1546,7 & 18165,8 \\
\hline$\%$ & 18,1 & 34,3 & 9,0 & 30,1 & 8,5 & 100,0 \\
\hline
\end{tabular}

General average of emissions of all individual greenhouse gases (GHG) and the carbon dioxide equivalent per $\mathrm{kW} \cdot \mathrm{h}$ in Slovenia from 2009 to 2014 amounts to $0,460 \mathrm{~g}$ [13]. Tab. 4 shows the carbon dioxide equivalent $\left(\mathrm{CO}_{2}\right.$-eq), which is a product of the quantity (mass) of individual greenhouse gasses, multiplied by their global warming potential. The obtained value enables the impact of different greenhouse gasses to be combined in the same unit, representing the unified carbon footprint. It is measured with unit of carbon dioxide equivalent $\left(\mathrm{CO}_{2}\right.$-eq).

Tab. 5 shows emissions across sectors [15]. Energyrelated greenhouse gas emissions are caused by fuel combustion in electrical energy sources, heating, transport, processing industries and construction, as well as in services and households. In addition, the emissions which are not generated directly by fuel combustion, but are connected to energy, i.e. fugitive emissions, which are generated by coal mining (collieries), transport and natural gas distribution, as well as by flue gas desulphurisation.

Electrical energy in Slovenia is generating the approximate average of $0,43 \mathrm{~kg}$ of $\mathrm{CO}_{2}$ emissions per $\mathrm{kWh}$ of energy produced [13]. In the 2012 study, the CARB (California Air Resource Board) department performed the analysis by calculating the energy demands and $\mathrm{CO}_{2}$ equivalent emissions of a traditionally used - conventional petrol vehicle (CV), a combination of electric motor and internal combustion engine - hybrid vehicle (HV), and also a battery electric vehicle (BEV) throughout their lifecycle. The study was founded as a support to the California Climate Change Legislation. The results of used hybrid model are calculated by weighted-average parameters of $\mathrm{CV}$ and BEV. Archive data used in the paper are based on the California GREET model, ANL (Argonne National Laboratory) findings and scientific sources in peer-reviewed literature. Several cases of the models are tested as sensitivity analyses on variation of input parameters and initial assumptions such as carbon emissions of petrol and electricity, different portions of electric rated power, electric battery rated power and reliability and fuel use. The calculations of techno-economic parameters (efficiency) of each vehicle type are performed and it is easy to see that $\mathrm{HV}$ is the best vehicle in efficiency and $\mathrm{CO}_{2}$ equivalent emissions. The calculations of total present value costs of all types of vehicles are performed too and as a result the $\mathrm{HV}$ are the cheapest during their lifetime, $\mathrm{CV}$ are in the middle and as the most expansive are BEV.

The most important aim of this research is to define the environmental influence of each type of vehicles, considering the lifetime energy use, $\mathrm{CO}_{2}$ equivalents emissions and also air pollution emissions. Considering environmental influence, the BEV are vehicles with the least overall impact, $\mathrm{HV}$ are in the middle and $\mathrm{CV}$ are vehicles with most significant influence [16]. The results of the study are presented in Fig. 3. 


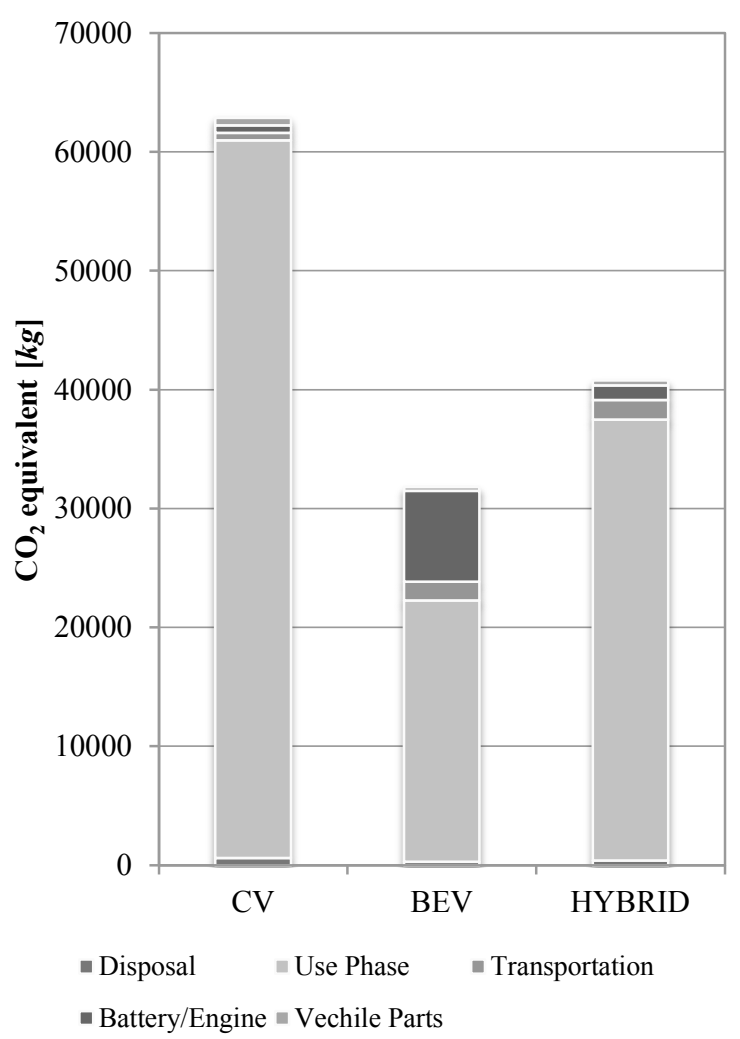

Figure 3 Emissions of the vehicles according to lifecycle phases [16]

As presented in the Fig. 3, the impact of electric vehicles on transport emissions - in the phase where they are driven directly by electrical energy or driven by hybrid motors is meter of research.

\subsection{Example of an Electric Vehicle for Emission Calculation}

In this case scenario, model is used to find optimal size of the system for power supply for period from $1^{\text {st }}$ June to $31^{\text {st }}$ August. Different values of loss of load probability $(L O L P)$ in this case scenarios are assumed. Optimal size of the off-grid system for following values of $L O L P$ is determined: 0,$00 ; 0,01 ; 0,02 ; 0,03 ; 0,04 ; 0,05 ; 0,06 ; 0,07$; 0,$08 ; 0,09 ; 0,10$, and 0,15 , respectively.

\subsection{Emission Impacts of e-Mobility Introduction}

Tab. 6 shows the average mileage in Slovenia. Considering that the average electric car needs $0,2 \mathrm{kWh} / \mathrm{km}$, calculation gives need of $2530,6 \mathrm{~kW} \cdot \mathrm{h} /$ year for each car.
Table 6 The average mileage of private cars [20]

\begin{tabular}{|l|c|c|c|}
\hline & All fuel & Petrol & Diesel \\
\hline Average $(\mathrm{km})$ & 12653 & 10235 & 16879 \\
\hline
\end{tabular}

If it is assumed replacing the total number of classic cars with the electric versions, it can be calculated how much electrical energy would be needed in total at the EV charging stations, neglecting any additional losses. For the entire fleet of private cars on 31 December 2014 (1068362 cars), we would need $2703,6 \mathrm{GW} \cdot \mathrm{h} /$ year. The annual use of energy to power the entire fleet of electric cars means $20 \%$ of the annual production of electrical energy on the power plants threshold (without energy produced in Nuclear Power Plant for Republic of Croatia), or $21,5 \%$ of the end energy use. This definitely means that the energy use would increase by the mentioned percentage, from current 12560 $\mathrm{GW} \cdot \mathrm{h}$ on $15264 \mathrm{GW} \cdot \mathrm{h}$, which would, of course, be more than the current production.

If it is assumed that the structure of energy sources for production of additional capacity is about the same as it was in 2013, the increase in $\mathrm{CO}_{2}$ emissions at electrical energy conversion could be calculated. Thus, for electric vehicles $1222 \mathrm{kt}$ of $\mathrm{CO}_{2}$ per year would be emitted. Considering that approximately $62 \%$ of the transport energy represents private cars, it can be assumed that they also cause as many emissions, amounting to the total emission of $3390,1 \mathrm{kt}$ of $\mathrm{CO}_{2}$ per year. Using these calculated data, we can now evaluate, that the emissions would be $64 \%$ lower than they are today, taking into account only emissions from private cars.

\section{DISCUSSION}

In the Republic of Slovenia, the share of energy from renewable sources, which actually fully justifies the feasibility of introducing electric vehicles, is a bit over $13 \%$. The importance of renewable energy sources in the case of electric vehicles is inversely proportional to the harmful emissions; the greater is the share of renewable energy sources, the lower is the share of harmful emissions. Table 7 shows the status of emissions assuming the introduction of electric vehicles. Decreasing emissions in private transport for $1745,9 k t \mathrm{CO}_{2}$ represents only $9,6 \%$ of reduction of total emissions according to the data from the year 2013, and the fact that at the introduction of complete electric mobility in private transport, private cars still represent only around $8 \%$ of the sources of emissions.

Table $7 \mathrm{GHG}$ emissions considering electric cars

\begin{tabular}{|c|c|c|c|c|c|c|c|}
\hline & $\begin{array}{c}\text { Non-energy related } \\
\text { sources }\end{array}$ & $\begin{array}{l}\text { Electricity and heat } \\
\text { production (incl. } \\
\text { fugitive emissions) }\end{array}$ & $\begin{array}{c}\text { Industry and } \\
\text { construction (energy } \\
\text { use of fuels) }\end{array}$ & Transport & $\begin{array}{c}\text { Transport - } \\
\text { only private } \\
\text { vehicles }\end{array}$ & $\begin{array}{c}\text { Other } \\
\text { (wide use) }\end{array}$ & Total \\
\hline $\begin{array}{c}2013 \\
\mathrm{kt} \mathrm{CO}-\text { eq }\end{array}$ & 3287,6 & 6230,9 & 1641,5 & 2069,0 & 3390,1 & 1546,7 & 18165,8 \\
\hline
\end{tabular}

Results can be also evaluated through the aspect of primary energy efficiency. For comparison a classic vehicle is selected on the one hand, with the internal combustion engine and the average efficiency. On the other hand, an 
electric vehicle is selected for comparison, which uses thermal power plant as a source of energy. Taking into account the efficiencies according to the energy chain [21, $22,23]$ and traffic modelling [24], the differences between electric vehicles and vehicles with internal combustion engines are identified. Despite the significantly higher efficiency of the first, the difference is actually relatively small, mainly because of losses when converting energy in the power plant, and due to losses in battery conversions. Thus, it can be concluded that the electric car has a little more than twice better efficiency of the primary energy. In our calculation it is not considered the possible energy recovery through regenerative braking system, which, according to some estimates [21], increases the efficiency of the vehicle itself by $17 \%$. When dealing with efficiencies, of course it has to pay attention to the correct interpretation, since estimating emissions through the energy efficiency is valid only as long as the chemical energy of fossil fuels is used. In the case of the use of renewable energy sources, which have relatively poor energy efficiency, this comparison is not purposeful.

\section{CONCLUSION}

E-mobility or the introduction of electric vehicles brings a more efficient use of energy in road transport. Electric vehicles reduce greenhouse gas emissions. At the current structure of electrical energy conversion in Slovenia, $\mathrm{CO}_{2}$ emissions of a simple battery electric vehicle are $64 \%$ lower than in a classic drive vehicle. This number can vary greatly depending on the electrical energy source. Electric vehicles are also an advantage for local emissions. Residents of some Slovenian cities are exposed to serious concentrations of $\mathrm{NO}_{2}$ and dust particles PM10, which largely originate from transport. Excessive contamination with dust particles in Slovenian cities is a serious environmental problem, which is why the European Commission initiated the procedure at the EU Court of Justice against Slovenia for violating the environmental protection.

According to the obtained results, a partial reduction in emissions of greenhouse gasses is needed. However, analyzed problem is very dependent on future investments in renewable sources; moreover electrical energy application cannot be possible without serious global alliances and collaborations.

Transport driven by electrical energy from own sources would of course mean an increased financial, political and technological independence, and can function as some sort of a lift for the standard of Slovenia. Economically speaking, society could gain a lot, because there would be no more imported primary energy from petroleum products, coming from elsewhere; closely related is also the independency from foreign sources and supply which can at the same time also mean less political influence from the outside. Nevertheless, energy independence is also preferred by the EU.

The immediate introduction of the electric cars presents a problem also due to the load of the power grid. A drastic increase in the number of electric cars, by taking into account the current configuration of the electrical energy system, would also represent a problem for the distribution.

\section{REFERENCES}

[1] Agencija Republike Slovenije za okolje. Raba končne energije po sektorjih: Kazalci okolja v Sloveniji. http://kazalci.arso.gov.si/?data=indicator\&ind_id=717. (2016, January 18)

[2] Statistični urad Republika Slovenija, medijsko središče, SISTAT. http://www.stat.si/StatWeb/prikazi-novico?id=5227\& idp=22\&headerbar=19. (2015, May 28)

[3] Republika Slovenija Ministrstvo za infrastrukturo. Energetski koncept Slovenije, Portal energetika, Direktorat za energijo. http://www.Energetika-portal.si/dokumenti/strateski-razvojnidokumenti/energetski-koncept-slovenije/. (2015)

[4] Agencija RS za okolje. Izpusti toplogrednih plinov iz prometa: Kazalci okolja v Sloveniji, Institut Jožef Stefan. http://kazalci.arso.gov.si/?data=indicator\&ind_id=627. (2014, September 9).

[5] Česen, M., Staničić, D., Urbančič, A., Levstek, M., Babuder, M., Beravs, F., Kopač, J., Lah, T., Merše, S., Nemac, F., Stojanovič, B., Svoljšak, M., Škornik, S., Volfand, J., \& Žebeljan, D. (2009). Obnovljivi viri energije (OVE) v Sloveniji (pp. 37-48 and 127-131). Celje: Fit media d.o.o., ISBN 978-961-6283-34-2.

[6] Agencija za energijo. Elektromobilnost. http://www.agenrs.si/ documents/10926/20705/PUB 20121211 Elektromobilnost VFinal-Rev_1_1790.pdf. (2012, December 11)

[7] Senožetnik, A. Pogoji so, električnih avtomobilov pa je zdaj še zelo malo. http://www.gorenjskiglas.si/article/ 20160409/C/160409774/1038/po-goji-so-elektricnihavtomobilov-pa-je-zdaj-se-zelo-malo. (2016, April 9)

[8] Ministrstvo za infrastrukturo Republike Slovenije. Akcijski načrt za energetsko učinkovitost za obdobje 2014-2020. (2015). Ljubljana: s.n.

[9] Agen. Poraba končne energije v prometu: Kazalci okolja v Sloveniji. http://kazalci.arso.gov.si/?data=indicator\&ind_id $=680 .(2013$, September $)$

[10] Agencija Republike Slovenije za okolje. Energetska učinkovitost in raba energije v sektorjih rabe končne energije: Kazalci okolja v Sloveniji. Jožef Stefan Institute. See http://kazalci.arso.gov.si/?data=indicator\&ind $i d=724$. (2015, November 14)

[11] Energija plus d.o.o. Sestava primarnih virov za proizvodnjo električne energije. http://www.energijaplus.si/za-dom/ pomoc-in-podpora/sestava-primarnih-virov-za-proizvodnjoelektrike. (2014)

[12] Ministrstvo za infrastrukturo. Statistika. Portal Energetika, Statistični urad RS. http://www.energetika-portal.si/statistika/. (2014).

[13] GEN energija. Nizkoogljična proizvodnja električne energije: Proizvodnja, GEN energija. http://www.gen-energija.si/ proizvajamo/trajnostna-proizvodnja. (2015).

[14] Institut Jožef Stefan. Izpusti $\mathrm{CO}_{2} / \mathrm{TGP}$ na enoto električne energije. Center za energetsko učinkovitost. http://www.rcp.ijs.si/ceu/sl/izpusti-co2tgp-na-enotoelektricne-energije. (2016).

[15] Agencija Republike Slovenije za okolje. Izpusti toplogrednih plinov energetskega izvora: Kazalci okolja v Sloveniji. Institut Jožef Stefan. http://kazalci.arso.gov.si/?data= indicator\&ind_id=705. (2016, January 18).

[16] Mediamatters for America, California Air Resources Board. 
Experts Respond To Distortions Of Electric Car's Environmental Benefits. http://mediamatters.org/blog/ 2013/03/13/experts-respond-to-distortions-of-electric-cars/ 193040. (2013, Marth 13).

[17] SUZUKI. Splash 2007 - Present: Autoevolution. http://www.autoevolution.com/cars/suzuki-splash-2007.html \#aeng_suzuki-splash-2007-10. (2013).

[18] German E cars GmbH. Elektrifizierte Personenwagen. http://www.german-e-cars.de/Personen-wagen.357.0.html? $\& \mathrm{~L}=0 \% 3 \mathrm{C} \% 2$ Fref. (2010).

[19] Laurent, J. M. The Stromos: For Germans Who Can't Wait for an Electric Car. Plugincars. http://www.plugincars.com/ stromos-german-e-cars-old-school-those-who-dont-wantwait-107199.html. (2011, May 17). See

[20] Statistični urad Republike Slovenije. Povprečno število prevoženih kilometrov in poraba goriva osebnih avtomobilov. Podatkovni portal SI-STAT. http://pxweb.stat.si/pxweb/ Dialog/varval.asp?lang=2\&ma=1815420S\&path=../Database/ Okolje/18_energetika/07_18154_poraba_gospodinjstva/\&ti=. (2014).

[21] U.S. Department of Energy. Where the Energy Goes: Electric Cars. Fueleconomy. https://www.fueleconomy.gov/feg/atvev. shtml. (2016).

[22] Grobljar, D. (2009). Ogrevanje hibridnih in električnih vozil. Fakulteta za pomorstvo in promet, Portorož, UDK 629.331(043.2).

[23] Markowitz, M. Wells to wheels: electric car efficiency. Energy Matters. See https://matter2energy.wordpress.com/ 2013/02/22/wells-to-wheels- -electric-car-efficiency/.(2013, February 22).

[24] Kurnaz, İ. (2016). Urban traffic modeling with microscopic approach using cellular automata. Technical Gazette, 23(6), 1565-1570. https://doi.org/10.17559/TV-20140601114314

\section{Authors' contacts:}

Simon MUHIČ, Ph.D. Associate Professor Faculty of Technologies and Systems Na Loko 2, 8000 Novo mesto, Slovenia +386 7393 0019, simon.muhic@guest.arnes.si

Ante ČIKIĆ, Ph.D. Associate Professor Mechanical Engineering Faculty in Slavonski Brod Trg Ivane Brlić Mažuranić 2

35000 Slavonski Brod, Croatia

+385 35493444, acikic@vtsbj.hr

Jadran PIŠTAN, B.Sc.

Faculty of Technologies and Systems

Na Loko 2, 8000 Novo mesto, Slovenia

+386 7393 0019, jadran.pistan@yahoo.com

Marinko STOJKOV, Ph.D., Full Professor

Mechanical Engineering Faculty in Slavonski Brod

Trg Ivane Brlić Mažuranić 2

35000 Slavonski Brod, Croatia

+385 35493444, mstojkov@sfsb.hr

Mladen BOŠNJAKOVIĆ, Ph.D., Senior lecturer

College of Slavonski Brod

Dr. Mile Budaka 1

35000 Slavonski Brod, Croatia

+385 35492634, mladenb@vusb.hr 